\title{
Critical Review of the
}

San Juan Peneplain

Southwestern Colorado

GEOLOGIGAL SURVEY PROFESSIONAL PAPER 594-I

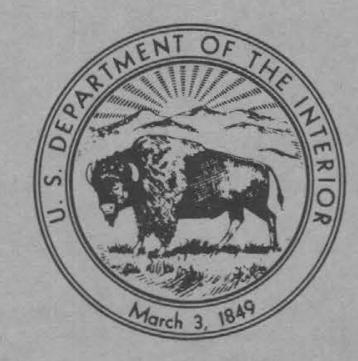



Critical Review of the

San Juan Peneplain

Southwestern Colorado

By THOMAS A. STEVEN

SHORTER CONTRIBUTIONS TO GENERAL GEOLOGY

GEOLOGICAL SURVEY PROFESSIONAL PAPER 594-I

The volcanic and geomorphic history of the San Juan Mountains indicates no peneplain cycle of erosion between the end of major volcanism and the present time

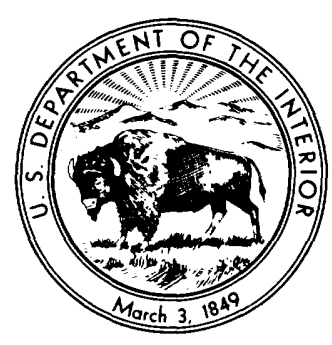

UNITED STATES GOVERNMENT PRINTING OFFICE, WASHINGTON : 1968 


\section{UNITED STATES DEPARTMENT OF THE INTERIOR \\ STEWART L. UDALL, Secretary \\ GEOLOGICAL SURVEY \\ William T. Pecora, Director}




\section{CONTENTS}

Abstract

Acknowledgments -.

General geology of the San Juan region

The peneplain concept

Discussion of the San Juan peneplain .

1. Subsidence of the prevolcanism erosion surface

2. Volcanism and volcano-tectonic deformation in the central San Juan Mountains
Page

I 1

1

2

2

4

6

6

Catalog of peneplain remnants

7 References cited _...
Page

I 8

9

10

12

13

14

14

\section{ILLUSTRATION}

Plate 1. Geologic map, San Juan region, Colorado, showing relations of the San Juan Peneplain of Atwood and Mather 



\title{
SHORTER CONTRIBUTIONS TO GENERAL GEOLOGY
}

\section{CRITICAL REVIEW OF THE SAN JUAN PENEPLAIN, SOUTHWESTERN COLORADO}

\author{
By Thomas A. Steven
}

\begin{abstract}
The San Juan peneplain has been described as a widespread surface of low relief cut in late Tertiary time on the San Juan Mountains of southwestern Colorado. A review of the geologic relations of many local flat areas that were interpreted to be remnants of this surface indicates that in most of these areas the flatness reflects somewhat modified original constructional surfaces, stripped surfaces on resistant layers of rock, or exhumed surfaces of diverse origin. Bedrock structures now delineated by geologic mapping show little or no similarity to many of the structures that have been postulated on the basis of the peneplain concept. The detailed volcanic and geomorphic history of the central San Juan Mountains indicates no peneplain cycle of erosion between the end of major volcanism and the present time. Rather, the original surface of volcanic accumulation was only slightly modified from the end of major volcanic activity in late Oligocene and early Miocene time until regional epeirogenic uplift of the Southern Rocky Mountains in the late Cenozoic caused widespread erosion and canyon cutting.
\end{abstract}

\section{INTRODUCTION}

In 1932 Atwood and Mather published a monographic report on the physiography and Quaternary geology of the San Juan Mountains, southwestern Colorado, which summarizes the geologic history and discusses in detail the various processes that led to the present spectacular landscape of the region. Their report is the only comprehensive description of the landscape that is available, and it still serves as the standard reference on the subject. The fieldwork leading to their report was done largely from 1909 to 1924 , almost contemporaneously with the study on bedrock geology by Whitman Cross, E. S. Larsen, Jr., and associates (Larsen and Cross, 1956). Both final reports clearly indicate an interdependence and cross-fertilization of ideas, and in terms of the physiographic and volcanologic ideas then in vogue, both represented significant advances.

The present report is concerned primarily with only one of the aspects of geology discussed by the earlier authors, the concept of a widespread subsummit peneplain of late Tertiary age which Atwood and Mather called the San Juan peneplain. When proposed, this conceptual surface was perhaps one of the most thoroughly "documented" peneplains of its day, and since then it has been accepted by most authors dealing with the general geologic history of the region. A wide variety of geologic problems in adjacent areas have been interpreted in the light of relations postulated for the peneplain.

Subsequent, more detailed work done with the advantage of increased geologic knowledge and newer concepts has resulted in major revisions of many of the older ideas. The concept of a San Juan peneplain, like that of many another peneplain postulated during the early part of the century, is no longer tenable. This report is inevitably critical, and in large part negative, but it is in no way intended to supplant the physical description of the landscape that forms the fundamental core of the Atwood and Mather monograph.

As described by Atwood and Mather (1932, p. 20-26), the San Juan peneplain was cut in late Tertiary time, after all but the final stage of volcanic activity had occurred in the San Juan Mountains. Erosion reduced a high volcanic plateau to a lowland plain studded with residual hills or monadnocks; and peneplanation was followed by doming, which raised the center of the San Juan region 3,000 feet or more above its margins. This dome was then dissected by fluvial and glacial agencies; 
this dissection led to the present rugged mountainous terrain.

In considering the specific geologic relations of most of the individual peneplain remnants (see Atwood and Mather, 1932, pl. 2), by comparing bedrock structures with structures required by the peneplain concept, and by reconstructing the detailed volcanic and geomorphic history of many local areas, it has become evident that no widespread peneplain ever existed over major segments of the San Juan region in late Tertiary time. Those aspects of the late Cenozoic history of the Southern Rocky Mountains and Colorado Plateau that were deduced on the basis of such a surface need to be reviewed and revised.

\section{ACKNOWLEDGMENTS}

Accumulation of data leading to this review began in 1952-53 when fieldwork in the Summitville mining district first convinced me that something was awry with the concept of a San Juan peneplain as previously described. Data collection has been carried on since then as an adjunct to my other fieldwork in the central and eastern San Juan Mountains, and during this time I have rarely missed an opportunity to discuss the problem with any of my colleagues who had any interest in, or information on, the subject. I acknowledge all the help and encouragement $I$ have thus received and particularly thank those who contributed unpublished information for my use. Particular mention is made of the help received from J. C. Ratté, P. W. Lipman, W. S. Burbank, R. L. Smith, R. A. Bailey, J. C. Olson, D. C. Hedlund, W. R. Hansen, C. S. Bromfield, and A. P. Butler, all of the U.S. Geological Survey.

\section{GENERAL GEOLOGY OF THE SAN JUAN REGION}

Four major groups of rock units are exposed in the San Juan region (pl. 1), and all need to be considered in a review of the San Juan peneplain. Precambrian rocks are exposed in the Needle Mountains northeast of Durango, along the Gunnison River and its tributaries, and in the southern part of the Sawatch Range in the northeastern part of the region. These are overlain by sedimentary rocks of Paleozoic, Mesozoic, and early Tertiary age along the east margin of the Colorado Plateau from Montrose to Pagosa Springs, and in places along the north margin of the region. The San Juan Mountains are made up principally of igneous rocks, which comprise probable Upper Cretaceous and lower Tertiary laccolithic intrusives along the west side of the region, and a great mass of middle Tertiary volcanic rocks and related intrusive rocks throughout the central part of the region. The San Luis Valley on the east side of the San Juan region is filled with Tertiary and Quaternary alluvial deposits derived from the adjacent mountains.

The Precambrian rocks, although highly varied, for present purposes can be considered as a unit of crystalline metamorphic and igneous rocks underlying most of the sedimentary and volcanic rocks and exposed in the cores of anticlinal uplifts. In general, the Precambrian rocks are resistant and stand as rugged mountains where uplifted, as in the Needle Mountains and southern Sawatch Range.

The distribution of the various sedimentary rocks is controlled for the most part by tectonic features. Paleozoic rocks are present mainly in the southwestern and northeasternmost parts of the region, but were eroded from a late Paleozoic uplift_-the Uncompahgre-San Luis highland-in the central and northern parts of the area. Mesozoic rocks cover most Paleozoic rocks and overlap their eroded edges onto the older highland, except around the flanks of the Needle Mountains uplift.

All these rocks were deformed during the Laramide orogeny in Late Cretaceous and early Tertiary time. An arch marked by the Uncompahgre Plateau extends southeastward into the San Juan region and is there overlapped by younger volcanic rocks. The Needle Mountains uplift projects southwestward from the main Uncompahgre arch and forms a prominent dome northeast of Durango. Elsewhere, the sedimentary rocks were warped into broad shallow folds, including the broad San Juan basin of northern New Mexico and southern Colorado.

Fluvial and related sediments were deposited in basins that developed in latest Cretaceous and early Tertiary time, and some of these deposits contain abundant volcanic debris that has been interpreted to indicate nearby volcanic accumulation, perhaps associated with some of the laccolithic centers (Burbank and Lovering, 1933, p. 297-298; Shoemaker, 1956, p. 162). Direct evidence for an age between Late Cretaceous and middle Tertiary for one of the laccolithic centers can be seen at Ouray, where the intrusives cut Mancos Shale of Late Cretaceous age and are in part overlain unconformably by Telluride Conglomerate (Burbank, 1940, p. 200; Luedke and Burbank, 1962) of probable early Tertiary age.

Erosion following early Tertiary deposition cut 
deeply into the sedimentary rocks and exposed resistant Precambrian rocks in the cores of the Needle Mountains and Sawatch uplifts and, locally, along the top of the Uncompahgre arch. Fluvial deposits of the Telluride Conglomerate and Blanco Basin Formation accumulated locally on the erosion surface, particularly near the Precambrian rocks exposed in the cores of the Laramide uplifts. The ages of the Telluride Conglomerate and Blanco Basin Formation have not been established definitely, but the Blanco Basin has been correlated on the basis of lithologic and stratigraphic similarities with the early Eocene San Jose Formation in the central part of the San Juan Basin (Kelley, 1955, p. 86; Van Houten, 1957, p. 386; and Simpson, 1948, p. 382).

Major volcanic activity broke out in the San Juan region following deposition of the Telluride Conglomerate and the Blanco Basin Formation. Inasmuch as major volcanism ended near the close of Oligocene time (Steven and others, 1967), it must have begun some time in the Eocene or early Oligocene. In the western San Juans, the earliest volcanic activity resulted in deposition of rhyodacitic pyroclastic breccias and tuff, reworked volcanic debris, and local lava flows of the San Juan Formation to a thickness of 3,000 feet over an estimated 2,400 square miles (Luedke and Burbank, 1963, p. C41). Eruption of this great mass of material led to subsidence of the general vent area between Silverton and Lake City to form a volcanic depression nearly 30 miles long and 15 miles wide. Alternating lavaflow and pyroclastic eruptions deposited the Silverton Volcanic Group mostly within this depression, and volcanic activity culminated in great ashflow eruptions of the Potosi Volcanic Group (Luedke and Burbank, 1963). The Silverton and Lake City cauldrons, nested within the earlier San Juan volcanic depression, subsided in response to the Potosi eruptions.

In the eastern San Juans, volcanic activity began at a few widely scattered centers and increased to widespread eruption and accumulation of andesitic to rhyodacitic lavas and breccias of the Conejos Formation, which forms the largest volcanic accumulation in the San Juans. The comparative age relations of the Conejos and San Juan Formations are not known, but both directly overlie prevolcanism Telluride and Blanco Basin fluvial deposits, and they may have been erupted at about the same time.

Volcanism shifted to the central San Juans during the last major period of activity, and a great rhyo- litic to quartz latitic ash-flow field formed around a source area near Creede. Cauldron subsidence accompanied many of the recurrent ash-flow eruptions, and at least six overlapping cauldrons have been recognized within an area about 50 miles long and 15-25 miles wide. The youngest of these, the San Luis Peak caldera, north of Creede, and the Creede caldera, south of Creede, bear on consideration of the San Juan peneplain as their form is still reflected in the present topography. Potassiumargon age determinations (Steven and others, 1967) indicate that the oldest unit in the central San Juan sequence, the La Garita Quartz Latite, was erupted in late Oligocene about 27.8 million years ago.

A series of summit volcanoes, consisting largely of viscous rhyolite and quartz latite flows, domes, and related breccias called Fisher Quartz Latite by Larsen and Cross (1956, p. 172), formed along the crest of the San Juan volcanic field. Two of the largest areas of Fisher Quartz Latite are associated with the Creede and San Luis Peak calderas and resulted from the last of a long sequence of related eruptions that earlier led to the extensive ash flows and cauldron subsidences. A similar accumulation to the southeast near Summitville (Steven and Ratté, 1960a) does not show any such clear-cut affinities to the underlying rocks and structures. Potassium-argon age determinations (Steven and others, 1967) indicate that the type Fisher Quartz Latite along the south margin of the Creede caldera was erupted near the end of the Oligocene-about 26 million years ago-whereas one of the youngest flows at Summitville was erupted significantly more recently-about 20.5 million years ago.

Fluvial gravels accumulated here and there within the San Juan region late in the period of volcanic activity, and these have been called Los Pinos Gravel, Bridgetimber Gravel, and Bayfield Gravel. According to Atwood and Mather (1932, p. 92, 101) the Bayfield Gravel is slightly older than the Bridgetimber and Los Pinos Gravels, which presumably are lateral equivalents. They believed that all the gravels accumulated within and along the flanks of the volcanic pile in either Pliocene or early Pleistocene time. Atwood and Mather (1932, p. 100-101) and Cross and Larsen (1935, p. 94-95) interpreted the Los Pinos as a member of the Hinsdale Formation resting on the San Juan peneplain, whereas Larsen and Cross $(1956, \mathrm{p} .186)$ considered it to be a lateral equivalent of their Fisher Quartz Latite and, thus, to underlie the peneplain. The correlation of these widely sepa- 
rated patches of gravels without more specific evidence than was cited seems hazardous, and the equivalencies that have been inferred are tenuous. (For further discussion see "Postpeneplain Alluviation and Volcanism.")

The last volcanic rocks erupted in the San Juans are widely scattered basaltic flows and locally associated rhyolitic lavas; these have been included together in the Hinsdale Formation (Larsen and Cross, 1956, p. 193). Potassium-argon age determinations (Steven and others, 1967) have shown that the rhyolite at the base of the succession in the central San Juan Mountains is 22-23 million years old, whereas the overlying basalt flows are 12-15 million years old, and that, in this vicinity at least, the two rock types should not be included in the same formation. No evidence is now available to establish the age of the widespread basalt flows in the eastern San Juans relative to the dated flows in the central San Juans, except to note that they all are late in the local sequence in which they occur, and all rest unconformably on the intermediate to silicic volcanic rocks that make up the great bulk of the volcanic field.

The San Luis Valley along the east side of the San Juan region is a great alluvium-filled segment of the Rio Grande trough, a complex graben zone that extends northward from southern New Mexico to the vicinity of Leadville in central Colorado. The San Luis Valley is a downthrown block between the San Juan Mountains on the west and the Sangre de Cristo Mountains on the east. The details of structure are obscured by alluvial fill, but phyiographic evidence for faulting is most conspicuous along the east margin of the valley, where coalescing alluvial fans are steeper and smaller than the broad low fans from the west, and the steep front of the mountains is marked by truncated gullies and faceted spurs. The buried structure along the west side of the valley and the relation of volcanic activity to this structure are not known. A deep oil test (Powell, 1958, p. 275-280) drilled in the valley about 29 miles northeast of Del Norte (pl. 1) was bottomed below sea level after penetrating more than 5,000 feet of alluvial fill and then nearly 3,000 feet of volcanic material without reaching any of the Mesozoic, Paleozoic or Precambrian rocks that constitute the higher peaks of the Sangre de Cristo Mountains which range from 12,000 to more than 14,000 feet in altitude. These pre-Tertiary rocks underlie the volcanic rocks of the San Juan Mountains at altitudes generally from 8,000 to 10,000 feet along the north and southwest sides of the mountains. Baltz (1965, p. 2073) postulated that the San Luis Valley is an eastward-tilted fault block that was depressed and alluviated after most of the volcanic activity in the San Juans, an interpretation that seems plausible although not yet proved.

\section{THE PENEPLAIN CONCEPT}

The San Juan peneplain was conceived when most physiographers enthusiastically supported the cycleof-erosion concept as proposed by W. M. Davis. Ancient peneplains, the natural end products of such cycles, were projected across many mountain ranges, particularly those with accordant ridge crests or high-level areas of low to moderate relief. The concept was applied widely throughout the Southern Rocky Mountains (Davis, 1911; Lee, 1922; Little, 1925; Mather, 1925; Blackwelder, 1909; Van Tuyl and Lovering, 1935), and the San Juan peneplain was but one of many.

According to Atwood and Mather (1932, p. 20 21 , the San Juan peneplain was cut from a high volcanic plateau during the interval between the Fisher and Hinsdale eruptive periods. As described by them, the peneplain's development progressed through a typical Davisian erosion cycle, from youth, through maturity, to old age; but before all the local monadnocks had been reduced to base level the entire region was upwarped, and rejuvenated streams have since carved out the present rugged terrain.

The concept of a summit peneplain was first developed along the south flank of the San Juan Mountains northeast of Durango, where numerous accordant ridge crests and relatively flat summit areas clearly reflect an old erosion surface. The original description by Atwood and Mather (1932, p. 22) characterizes the area well:

The divide between the Florida and Animas Canyons, for example, is a gently undulating upland surface 1 to 2 miles in width, rising gradually from an altitude of 9,000 feet at the south to 12,000 feet 10 miles to the north, in the vicinity of the Needle Mountains. Neighboring divides on each side, which separate similar southward-trend valleys, have similar altitudes increasing regularly toward the center of the mountains. In the foothill zone numerous hogback ridges rise to altitudes of 8,000 to 9,000 feet, so arranged that a surface projected across their summits rises gently toward the mountains and coincides with the intercanyon uplands. Outlying mesas and plateaus, such as Bridge Timber Mountain and the Mesa Mountains, display remarkably smooth tops, which likewise slope gently away from the San Juan Mountains. These outliers carry the restored graded surface downward to an altitude of about 7,000 feet at the Colorado-New Mexico State line. 
Extrapolating from these well-defined remnants, Atwood and Mather (1932, p. 21-23) found many isolated high-level flat to gently rolling areas that seemed also to represent fragments of an old erosion surface. Most of these are simply high-level surfaces with altitudes generally accordant with others nearby, but a few are veneered with patches of gravel, and others by basaltic lava flows of the Hinsdale Formation. Mountain tops that project above the general level of the high, flat areas were believed to represent monadnocks. Integrating all these features, Atwood and Mather assembled a conceptual lowland plain locally studded with residual hills and drained by sluggish meandering streams.

This conceptual plain was contoured at 500 -foot intervals (Atwood and Mather, 1932, pl. 2), and the representation obtained is summarized on plate 1 of this report. The surface is irregular, as they described it (Atwood and Mather, 1932, p. 24):

As thus restored the peneplain surface is nowhere smooth and horizontal. Considerable portions of it in the central part of the San Juan region now stand more than 13,000 feet above the sea. In the foothills and near the margin of the range its present altitude is generally less than 9,000 feet. Viewed in the large the peneplain surface arches gently over the San Juan Mountains. The surface of this dome is, however, complicated by numerous minor undulations, so that certain points upon the peneplain stand more than 2,000 feet above other points only 4 or 5 miles away.

To account for the gross and local irregularities on their peneplain surface, Atwood and Mather (1932, p. 24-25) appealed in part to local residual hills or monadnocks, but to a far greater extent to later deformation. The broad domal form of the surface, with the central area 12,000-13,000 feet above sea level and the marginal parts 7,000 9,000 feet, was taken to indicate broad crustal warping and uplift, and the smaller scale "arches," "sags," and "basins" were taken to indicate more local deformation. An abrupt discordance of the surface remnants near the center of the mountains was ascribed to offset along the Cannibal fault, and a similar discordance near the Gunnison River, to the Cimarron fault.

Drainage radiates outward from the higher parts of the San Juan Mountains, presumably reflecting an outward flow of consequent streams from the center of the updomed area. Atwood and Mather (1932, p. 25) called special attention to the Animas River, however, which starts near the north margin of the mountains and flows southward across the dome. This relationship was interpreted to indicate that the Animas River was sufficiently active to cut downward in pace with uplift and was thus able to maintain its ancestral course. Although Atwood and Mather did not call attention to the fact, the Rio Grande shows similar relationships; it heads in the western San Juan Mountains and flows eastward across the center of the range to the east margin at Del Norte.

Accelerated downcutting resulting from the postulated arching of the San Juan region at the end of the peneplain cycle was believed responsible for the deposition of the great alluvial fans around the margins of the mountains. These fans are particularly apparent along the west edge of the San Luis Valley, where Los Pinos Gravel is shown (Atwood and Mather, 1932, pl. 2) as overlapping the edges of the San Juan peneplain. The Hinsdale Formation was believed to have accumulated at about the same time, as recounted by Atwood and Mather (1932, p. 26):

While this process of sedimentation was continuing extensive flows of basaltic lava of Hinsdale age flooded hundreds of square miles of country. For the most part the lava floods were poured out on the newly deposited beds of gravel and sand in the piedmont and valley regions. In part, however, the lavas spread over bare rock surfaces in the eastern half of the domed area.

The concept of a San Juan peneplain as outlined above required corollary tectonic concepts. The area underlain by the volcanic rocks was believed to have subsided concurrently with accumulation. According to Atwood and Mather (1932, p. 19), "The surface beneath the Tertiary volcanic rocks in the San Juan Mountains is at the present time a great saucer tipped downward toward the east."

This subsidence was required to depress the bulk of the volcanic rocks now remaining in the San Juan Mountains to below base level of peneplanation; despite this required subsidence, Atwood and Mather (1932, p. 19-21) envisaged that the top of the volcanic pile stood 3,000-4,000 feet above its surroundings and that a significant but unspecified thickness of this pile was removed during the peneplain cycle of erosion. Following the peneplain cycle, the area that had previously subsided was domed to the form now shown by the reconstructed peneplain surface (pl. 1). This local doming apparently was superimposed on a postulated general uplift of Southwestern United States that took place at about the same time.

Salient features of the San Juan peneplain, as visaged by Atwood and Mather, that are discussed 
in the following review may be summarized as follows:

1. The area subsided concurrently with accumulation of the volcanic rocks, and the underlying erosion surface "is at the present time a great saucer tipped downward toward the east" (Atwood and Mather, 1932, p. 19).

2. The peneplain cycle of erosion, during the interval between the Fisher and Hinsdale eruptive periods, removed a significant thickness of rocks from above the level of the San Juan peneplain.

3. The principal evidence for the peneplain is the existence throughout the San Juan Mountains of many isolated high-level flat to gently rolling areas, which are interpreted as remnants of the peneplain. Some irregularities projecting above the conceptual surface are interpreted as monadnocks.

4. The broad domal form of the peneplain is the result of subsequent crustal uplift; small irregularities on the surface, other than monadnocks, resulted from smaller scale deformation. Two abrupt discordances are due to major faulting.

5. Great marginal alluvial fans indicate accelerated downcutting that followed regional arching at the end of the peneplain cycle. The Hinsdale Formation (chiefly basaltic lava flows) was erupted at about the same time and spread widely over the peneplain and marginal fans.

6 . The generally radial drainage pattern of the present San Juan Mountains reflects outward flow of consequent streams from the center of the domed San Juan peneplain area. The Animas River is an exception that cut downward rapidly enough to keep pace with uplift and maintain its course across the crest of the dome.

\section{DISCUSSION OF THE SAN JUAN PENEPLAIN}

The premise of this paper is that the geomorphic history of an area must be compatible with the geologic relations determined from the bedrock. In the paragraphs that follow, each of the six salient features summarized above is discussed in the light of the geologic structure and history determined from detailed and reconnaissance bedrock studies, many of which were done since the idea of the San Juan peneplain was conceived. The discussion includes an analysis of the geologic relations of nearly all the local surfaces interpreted by Atwood and Mather as peneplain remnants. The conclusion is that the concept of the San Juan peneplain is incompatible with the bedrock relations and should therefore be abandoned.

1. SUBSIDENCE OF THE PREVOLCANISM EROSION SURFACE

The area subsided concurrently with accumulation of the volcanic rocks, and the underlying erosion surface "is at the present time a great saucer tipped downward toward the east" (Atwood and Mather, 1932, p. 19).

This generalization is supported in part by the gross distribution and altitudes of exposure of the volcanic rocks, but it is an oversimplification that does not take into account many of the diverse elements in the structure of the San Juans. It is difficult at the present state of knowledge to separate the effects of irregular underlying topography, regional and local tectonic warping, volcano-tectonic subsidence and resurgence of caldera areas, and possible basining caused by the load of volcanic rocks, as postulated by Atwood and Mather.

Evidence for basining apparently depends on exposures of volcanic rocks at relatively low altitudes along an east-trending belt through the middle of the San Juan Mountains. These low exposures are best displayed in the Silverton-Lake City area in the western San Juans (alts near 9,000 ft) and in the Creede area in the central San Juans (alts near $8,400 \mathrm{ft}$ ). At these places, however, more recent geologic work has established the existence of major cauldron complexes, and these complexes account in part at least for the low position of the rocks.

Atwood and Mather (1932, p. 25) emphasized a general eastward tilting of the San Juan region toward the San Luis Valley, a tilting that seems indicated by the generally higher structural levels of the rocks in vicinity of the Silverton and Lake City cauldrons, in the western San Juans, relative to structural levels of the rocks along the east margins of the mountains near Del Norte. At least part of this difference in structural level reflects postvolcanism deformation, for the tilting is most obvious along the east margin and the Conejos River area of the San Juan Mountains, where welded ash-flow tuffs, sedimentary beds in the Los Pinos Gravel, and basalt flows in the Hinsdale Formation dip eastward and project under the alluvial fill of the valley; also, the tilting seems closely related to subsidence of the San Luis Valley. The base of the volcanic rocks around the north, west, and southwest sides of the San Juans (pl. 1) shows no indication of a general eastward tilt, but it ranges irregularly in altitude from 8,000 to 10,000 feet 
from the Cochetopa Creek area westward to Telluride, and from the Piedra River area southeastward to New Mexico. In the Needle Mountains area, where exposed Precambrian rocks stood high prior to volcanic activity, the base of the overlapping volcanic rocks rises to an altitude of more than 12,000 feet. A broad gentle syncline extends eastward across the central San Juans from the headwaters of the Rio Grande to the margin of the mountains at Del Norte, and in combination with the irregularly high position of the base of volcanics to the north, west, and south gives a basinlike structure to much of the volcanic field. Inasmuch as the syncline involves basaltic lavas of the Hinsdale Formation, it probably formed largely in postvolcanism time, and the basining may thus have had little to do with accumulation of the volcanic rocks.

Many of the structures in the volcanic rocks of the central San Juan Mountains near Creede are related to local caldera subsidence or postsubsidence doming, and no regional eastward tilting seems indicated. Layers of welded ash-flow tuffs dip gently eastward over some fairly extensive areas, but the same layers are flat or dip gently in other directions in nearby areas, and all are cut by faults of local volcano-tectonic origin. The Wason Park Rhyolite, a distinctive welded tuff (Steven and Ratté, 1964, p. D59), lies at the same altitudes-between 10,800 and 11,200 feet-over areas of several square miles or more in both the Clear Creek area, 15 miles west of Creede, and the headwaters of Alder Creek, 13 miles eastsoutheast of Creede. Clearly there is little difference in gross structural level of this formation over an east-west span of more than 25 miles across the central San Juans.

The north margin of the San Juan Mountains, from the divide between Cochetopa and Cebolla Creeks westward, shows many layers of differentially welded ash-flow tuffs inclined a few degrees northward toward the Gunnison River. Although irregular in detail, the underlying surface on Precambrian and Mesozoic rocks is also inclined northward, generally parallel to the welded-tuff layers.

Thus, a general basining and eastward tilting of the surface beneath the central and eastern parts of the volcanic pile seems to have occurred. However, the gross structure is complicated by so many local structures of diverse age and origin that it is difficult to determine which aspects are due to basining concurrent with accumulation and which to later deformation almost concurrent with postvolcanism foundering of the San Luis Valley.

2. VOLCANISM AND VOLCANO-TECTONIC DEFORMATION IN THE CENTRAL SAN JUAN MOUNTAINS

The peneplain cycle of erosion, during the interval between the Fisher and Hinsdale eruptive periods, removed a significant thickness of rocks from above the level of the San Juan peneplain.

The above assumption is invalidated by the recognition of many original constructional volcanic features in the central San Juan Mountains. Beginning with Burbank's (1933, p. 156-162) pioneer recognition of the Silverton cauldron, nested volcano-tectonic subsidence structures have been found in two main areas in the western and central San Juan Mountains (pl. 1). Of especial interest to the present review are the Creede and San Luis Peak calderas (Steven and Ratté, 1960b, 1965); these are the youngest and most prominent of the cauldron structures that have so far been recognized in the central San Juans, and the original form of these features is still reflected in the present topography. The Creede caldera is particularly well preserved, and the later history of its development is well understood.

The cauldron complex of the central San Juan Mountains developed concurrently with the eruptions that deposited the surrounding ash-flow tuffs. The last of these eruptions were of the Nelson Mountain Quartz Latite in the northern part of the field and the Snowshoe Mountain Quartz Latite in the central part of the field (Steven and Ratte, 1964, 1965). The San Luis Peak caldera subsided in response to the Nelson Mountain and earlier eruptions, and the Creede caldera in response to the Snowshoe Mountain eruptions. The cores of both calderas were resurgently domed following subsidence, and the uplifted blocks still constitute prominent high points in the present topography.

San Luis Peak in the core of the San Luis Peak caldera has an altitude of 14,014 feet and is the highest peak in the central and eastern San Juan Mountains. All the exposed rock beneath this peak is Nelson Mountain Quartz Latite, which has an aggregate thickness of more than 3,500 feet in the core of the caldera. Related welded tuffs outside the caldera range from 0 to 1,000 feet in thickness, but are only a few hundred feet thick in most places, and form high benches at altitudes above 12,000 feet along the Continental Divide east and west of San Luis Peak. No way is known to determine how much rock has been eroded from the 
tops of many of these benches. It seems to have been minor, however, as remnants of local Fisher Quartz Latite volcanoes rest on the Nelson Mountain tuffs west of the San Luis Peak caldera and indicate that the original top of the tuffs was only slightly higher than the tops of nearby benches not covered by Fisher lavas.

La Garita Mountain, which lies between the southeast margin of the San Luis Peak caldera and area marked (9) on plate 1 , is a high fault block of La Garita Quartz Latite that was uplifted early during the period of volcanic eruptions from the central San Juan source area. Younger ash-flow units, including the Nelson Mountain Quartz Latite, overlapped the margins of the block but may never have covered the higher parts, which still stand at altitudes of 13,488-13,895 feet. The original rough structural topography formed early in the volcanic history of the central San Juan area thus has persisted in modified form to the present time.

In the development of the well-displayed Creede caldera south of Creede, final subsidence left a nearly circular flat-floored basin below the present bed of the Rio Grande, which ranges in altitude from 8,400 to 8,800 feet. Steep walls extending up to present altitudes of about 10,500-13,000 feet surrounded most of the east, north, and west margins, and tangential grabens extended outward from the southwest and northeast margins (pl. 1). One of the graben faults west of the Creede caldera coincides in part with the Cannibal fault of Atwood and Mather (1932, pl. 2); the faulting here is definitely related to caldera subsidence or postsubsidence doming, however, and preceded the postulated peneplain cycle of erosion.

After subsidence, the core of the Creede caldera was strongly domed, and the center of the core, now marked by Snowshoe Mountain, was uplifted to well above a present altitude of 12,000 feet, but the margins remained near 8,000 feet. Viscous lava of Fisher Quartz Latite was erupted locally around the margin of the caldera, chiefly toward the south (pl. 1, area 11), where the lavas heaped up near the vents to form Fisher Mountain, Beautiful Mountain, and other volcanic domal mountains. Stream and lake sediments, ash beds, and travertine of the Creede Formation were deposited elsewhere in the structural moat around the caldera margin, filling the closed basin to the lowest place on the rim, which was along the graben extending southeastward from the caldera. The actual height of this outlet is not known; the topographically high- est lacustrine beds in the Creede Formation are at an altitude of about 10,000 feet, but fluvial beds in a tributary valley northwest of Creede are preserved at altitudes up to 10,700 feet. The sill of the outlet probably was not below the top of the hard Wason Park Rhyolite, which is near the present altitude of 11,000 feet. Although not conclusive, all these factors suggest that the top of the Creede Formation fill probably was at least at the level of the top of the Wason Park Rhyolite and perhaps significantly higher, but that it was not as high as the position of the San Juan peneplain, which in this vicinity was drawn across the tops of the high benches adjacent to the graben that provided the outlet (Atwood and Mather, 1932, pl. 2).

The domes and viscous flows of Fisher Quartz Latite along the south side of the Creede caldera still stand as rounded mountains extending above the general level of the surrounding terrain. Fisher Mountain and Beautiful Mountain (pl. 1, area 11) are local domal accumulations of quartz latite whose present rounded summits have been lowered from the original level of the flow tops by an unknown amount. However, the present high areas at least reflect the original constructional highs. Areas adjacent to these domal protrusions may never have attained the height postulated for the San Juan peneplain in this vicinity by Atwood and Mather (1932, pl. 2).

Although many of the original constructional forms still recognized in and adjacent to the central San Juan caldera complex were preserved by burial and were exhumed only recently, others were not, and the deep erosion required by the peneplain concept is precluded. At least some of the area apparently never reached the height postulated for the peneplain.

\section{THE PENEPLAIN REMNANTS}

The principal evidence for the peneplain is the existence throughout the San Juan Mountains of many isolated high-level flat to gently rolling areas, which are interpreted as remnants of the peneplain. Some irregularities projecting above the conceptual surface are interpreted as monadnocks.

Either from personal knowledge derived from field examinations, from reviewing published accounts, or from discussions with colleagues, I have been able to classify by origin most of the peneplain remnants shown by Atwood and Mather (1932, pl. $2)$. This was done as an initial step in reviewing the San Juan peneplain concept, and the information obtained is fundamental to much of this review. The classification that emerges from this 
analysis is shown below; numbers refer to localities on plate 1, and detailed discussions of the remnants are given in the catalog at the end of this report.

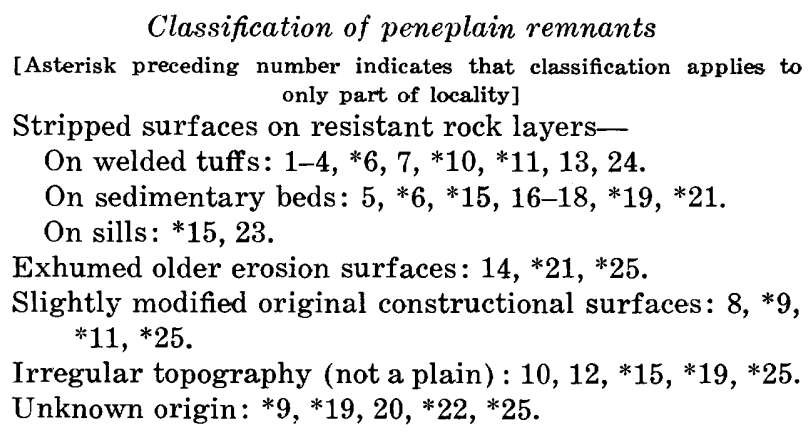

Most of the surfaces that were interpreted to be peneplain remnants reflect layers of resistant rock of one kind or another from which softer material has been stripped. Several factors militate against the hypothesis that these surfaces truly represent a late Cenozoic peneplain:

A. The remnants represent many different geologic horizons, from slightly modified original constructional surfaces to exhumed remnants of the early Paleozoic surface cut on hard Precambrian rocks. Most of the remnants can be explained readily without postulating regional peneplanation.

B. Only those stripped surfaces that conform to the envisaged configuration of the peneplain were included as remnants; those nearby but at different levels were excluded. Stripped surfaces at many levels commonly follow the tops of particularly resistant rock layers, and the resulting bench-and-tableland topography is typical of many terrains underlain by lowdipping strata of widely varying resistance.

C. Many of the inclined remnants are stripped surfaces on tilted layers of resistant rock. Tilting in some areas clearly preceded stripping, and regional base level had little control on local topographic form.

The origins of many individual remnants considered alone neither preclude nor require a former peneplain; however, considered in the context of bedrock geology, they appear to depend more on local control of erosion by resistant rock layers than on erosion to a regional base level as required by the peneplain concept.

\section{Postpeneplain Deformation}

The broad domal form of the peneplain is the result of subsequent crustal uplift; small irregularities on the surface, other than monadnocks, are the result of smaller scale deformation. Two abrupt discordances are due to major faulting.

The broad dome, like the peneplain itself, results from the integration of many high-level surfaces of diverse origins. No independent evidence has been cited in its support, and considerable evidence can be cited against it. (See "Subsidence of the Prevolcanism Surface," and "Volcanism and Volcano-tectonic Deformation in the Central San Juan Mountains.") In particular, the evidence cited indicating that much of the deformation responsible for the basinlike structure of the volcanic field is late, perhaps coincident with subsidence of the San Luis Valley, makes this conceptual broad dome unlikely.

The smaller scale deformation, on the other hand, postulates specific features that can be dealt with in terms of local geological relations. In part, the detailed arches and sags on the San Juan peneplain (pl. 1) coincide with the structure in the underlying rocks, but in all these places the so-called peneplain remnants expose hard layers of rock from which less resistant materials have been stripped. The structures reflected by these stripped surfaces vary widely in age, and differential erosion of deformed layers having different resistances seems to have been more important than erosion to a particular base level at a particular time.

Stripped surfaces are especially evident in the southeastern San Juan Mountains, where the socalled peneplain remnants are developed on inclined layers of differentially welded tuffs. (See 24, "Catalog of Peneplain Remnants.") These surfaces are generally parallel to the underlying layers and are in part covered by Los Pinos Gravel and basalt flows of the Hinsdale Formation; all were tilted eastward toward the San Luis Valley, beginning late in the period of volcanic activity and ending some time following the Hinsdale eruptions. Similarly, most of the remnants along the north side of the San Juan Mountains are stripped surfaces on hard layers of welded tuffs. (See under 1, 2, 3, 4, and 6, "Catalog of Peneplain Remnants.") These stripped surfaces dip gently north from the San Juan Mountains and south from the West Elk Mountains toward a low area along the Gunnison River and reflect the tops of warped resistant beds in the underlying layered units.

Differential erosion of interlayered hard and soft rocks also is reflected by the peneplain remnants around Rico (Cross and Ransome, 1905) and in the La Plata Mountains (Cross and others, 1899; Eckel, 
1949) northwest of Durango (pl. 1). Here, laccolithic intrusives, possibly of latest Cretaceous age (Shoemaker, 1956, p. 162), domed the adjacent sedimentary rocks. The peneplain remnants are almost all stripped surfaces on inclined hard sandstone beds or, in a few places, on igneous sills related to the laccolithic centers. (See under 15, 16, 17, and 18, "Catalog of Peneplain Remnants.") Doming was much earlier than the erosion, and the stripped surfaces appear to have formed with their present inclinations.

In other places the "arches" and "sags" on the San Juan peneplain (pl. 1) are not reflected in the underlying bedrock. The "sag" along the trend of the upper San Miguel River coincides with the southeast end of the Placerville anticline, a broad low fold in the southeastern part of the Paradox fold-andfault belt of the Colorado Plateau (Bush and others, 1960 , p. 468, fig. 45; 1961). The "arch" between the San Miguel River and Rico also has no counterpart in the bedrock, for Bromfield (1961) and Bromfield and Conroy (1963) showed sedimentary beds beneath this area to be flat or to dip gently northward everywhere except adjacent to intrusive igneous bodies.

The steep northwestern slope of the so-called Summitville arch (Atwood and Mather, 1932, pl. 2), which extends northeastward through area 25 (pl. 1), also appears not to be of structural origin. As described later under 25 in the section "Catalog of Peneplain Remnants," several of the small remnants of the San Juan peneplain along the top of this "arch" are somewhat modified original flow tops in a local pile of quartz latite lavas that stood above the surrounding terrain cut on older rocks. The abrupt northwest margin of the "arch" thus appears to reflect an outer constructional slope on this local volcanic accumulation.

The pronounced arch postulated on the peneplain in the southeastern San Juan Mountains near the Colorado-New Mexico boundary was obtained by integrating surface remnants of diverse origin. Those remnants on the east flank reflect stripped surfaces on hard layers of welded tuffs tilted eastward toward the San Luis Valley. The west flank of the arch, however, is represented by a single remnant near the State line south of Pagosa Springs. As mapped and described by Wood, Kelley, and MacAlpin (1948) and Dane (1948), this remnant is the stripped surface of an igneous sill that intruded the Animas Formation of Late Cretaceous and Paleocene age; structural contours and cross sections shown by these later workers indicate that broad anticlines and synclines occur in adjacent areas, but these structures do not conform to the postulated configuration of a deformed San Juan peneplain.

The "arches," "sags," and "faults" that presumably deform the San Juan peneplain throughout the central part of the San Juan Mountains (pl. 1) also were derived from integration of surface remnants of diverse origin. Any consideration of the peneplain in this area, however, is inextricably involved with details of volcanic history and has been presented under item 2 in the section "Volcanism and Volcano-Tectonic Deformation in the Central San Juan Mountains."

The abrupt discordances of the peneplain surface (pl. 1) were attributed by Atwood and Mather to major postpeneplain faulting. Their Cannibal fault coincides in part with one of the graben faults extending northwest from the Creede caldera, and this graben fault is definitely related to caldera subsidence and resurgence and preceded the postulated peneplain. The Cimarron fault does not offset the volcanic rocks (Larsen and Cross, 1956, pl 1), and according to W. R. Hansen (oral commun., 1965 ) is clearly prevolcanism in age.

In summary, the record of deformation indicated by bedrock structures is clearly incompatible with major doming and faulting and with smaller scale deformation of the peneplain inferred by Atwood and Mather.

\section{POSTPENEPLAIN ALLUVIATION AND VOLCANISM}

Great marginal alluvial fans indicate accelerated downcutting that followed regional arching at the end of the peneplain cycle. The Hinsdale Formation (chiefly basaltic lava flows) was erupted at about the same time and spread widely over the peneplain and marginal fans.

Alluvial deposits now represented by the Los Pinos, Bridgetimber, and Bayfield Gravels are scattered widely around the margins of the San Juan volcanic field. These deposits were believed by Atwood and Mather (1932, p. 84-101) to be approximate stratigraphic equivalents; the Bayfield Gravel was thought to have been deposited locally on the San Juan peneplain just prior to doming, and the Bridgetimber and Los Pinos Gravels were thought to represent alluvial fans deposited slightly later around the margins of the updomed San Juan region.

Available data are insufficient for detailed consideration of the equivalence or nonequivalence of all the scattered remnants of gravel that have been referred to these foundations. The available evidence does suggest, however, that many of these 
gravel deposits accumulated as the result of local rather than regional conditions, and that at least some of the earlier correlations are demonstrably wrong.

As described under item 1 in the "Catalog of Peneplain Remnants," W. R. Hansen (oral commun., 1964), found that gravel deposits near the Black Canyon of the Gunnison River referred by Atwood and Mather (1932, p. 86) to the Bayfield Gravel are actually interlayered with an extensive sequence of ash-flow tuffs. Thus, the gravels here are significantly older than the postulated peneplain cycle of erosion and represent deposition from streams that reestablished themselves throughout the area between periods of volcanic activity.

Detailed work by Butler (1946) in the TusasTres Piedras area, New Mexico, just south of the lower Conejos River area, shown on plate 1, has shown the Los Pinos Gravel there to be an assemblage of members of limited lateral extent that accumulated concurrently with local volcanic activity. Much of the debris in the Los Pinos Gravel in the Tusas-Tres Piedras area was derived from contemporaneous volcanism, rather than from erosion of preexisting rocks.

Larsen and Cross (1956, p. 185-186) reported similar relations in the area to the north, along the east flank of the San Juan Mountains in Colorado (pl. 1). In the Green Ridge-Chiquita Park area between Monte Vista and Alamosa Creek, the Los Pinos consists in large part of lava flows and pyroclastic rocks, which grade laterally southward into typical fluvial sediments of the formation. Larsen and Cross considered the Los Pinos to be equivalent in age to their so-called Fisher Quartz Latite at Summitville, and thus older than the peneplain cycle of erosion postulated by Atwood and Mather.

Richmond (1965) has shown that the type Bridgetimber Gravel near Durango, Colo., actually consists of two deposits of different ages and that both are probably of fluvioglacial origin. Nearby deposits mapped as Bayfield Gravel are probable correlatives of the type Bridgetimber, or are small accumulations of diverse origin.

As shown by Larsen and Cross (1956, pl. 1), the Hinsdale Formation consists largely of basaltic lava flows containing some rhyolite which occur in scattered patches throughout the northern, central, and eastern parts of the San Juan Mountains. The lava flows are at about the same levels as nearby smooth surfaces interpreted as remnants of the San Juan peneplain (Atwood and Mather, 1932, pl. 2) and have been cited as evidence for the existence of a San Juan peneplain (Kelley, 1957, p. 161). Both Atwood and Mather (1932, p. 26) and Larsen and Cross (1956, p. 206-207) suggested that the Hinsdale Formation was erupted from many scattered centers throughout the San Juan Mountains. Larsen and Cross cited several major centers of accumulation and postulated the existence of more. In more recent fieldwork, both $\mathrm{P}$. W. Lipman and I have found several small vent areas not connected with any of the larger remnants of Hinsdale lavas. The flows that were erupted from these multiple sources covered the existing surfaces around the local vents, and no widespread plain is required to account for the present distribution of flows.

No evidence is known to indicate that all the late basalts and rhyolites previously included in the Hinsdale were erupted during any given brief interval of time, and in the central San Juan area (near 8 , fig. 1) they definitely were not. In a series of remnants extending about 25 miles north from the upper Rio Grande, a distinctive white rhyolite welded tuff underlies a series of basalt flows. Potassium-argon determinations have shown that the rhyolite was erupted 22-23 million years ago, whereas the basalts were erupted 12-15 million years ago (Steven and others, 1967). It seems equally plausible that rocks in other remnants of the so-called Hinsdale would have been erupted at widely different times during the latter part of the Tertiary.

Remnants of the so-called Hinsdale Formation in the northern part of the San Juan region comprise two large areas, the Alpine Plateau (northeast of area 3, pl. 1) and Cannibal Plateau (southwest of area 6, pl. 1), as well as several smaller patches. At the north edge of the Alpine Plateau mass, W. R. Hansen (oral commun., 1964), has found remnants resting on stripped surfaces on welded ash-flow tuffs. According to J. C. Olson (oral commun., 1964), the small remnant south of area 4 , plate 1 , rests largely on a stripped surface on a densely welded ash-flow tuff, but southward it overlaps older rocks and extends onto a stripped surface on Precambrian rocks. Olson also has mapped some of the northernmost tongues of Hinsdale connected with the Cannibal Plateau mass (due west of area 6, pl. 1) and has found these to rest on stripped surfaces on densely welded ashflow tuffs. I found the same relationship on a reconnaissance traverse across the east margin of the area of the so-called Hinsdale Formation due east of Lake City. The surface covered by these remnants 
is therefore typical of the surfaces found in many ash-flow fields, where erosion of differentially welded layers forms widespread bench-and-table lands.

Farther south, in the vicinity of Spring Creek Pass (northwest and southwest of area 8, pl. 1), the Hinsdale Formation (Larsen and Cross, 1956) rests in part on the slightly modified original top of the Nelson Mountain Quartz Latite and in part on stripped surfaces of older welded-tuff layers and lava flows. Unbroken Hinsdale covers an erosion surface that bevels faults along the west side of the graben that extends northwestward from the Creede caldera, indicating that the faulting was older than the pre-Hinsdale period of erosion, rather than younger as interpreted by Atwood and Mather (1932, p. 24, pl. 2). To the east, this remnant of Hinsdale Formation projects toward an older faultline scarp 1,400 feet high along the east side of the graben, but the actual margin of the Hinsdale mass is obscured by glacial and landslide debris. This east border fault is locally covered by unbroken lava flows of Fisher Quartz Latite that poured down across the scarp, and it too must have been active earlier than the presumed peneplain cycle of erosion. The scarp was thus in existence when the Fisher Quartz Latite was erupted, about 26 million years ago, and has persisted, partially buried at times, to the present.

Southeast of the Creede caldera (near area 10, pl. 1) the Hinsdale Formation (Larsen and Cross, 1956) forms a tabular cap on top of the Wason Park Rhyolite, a widespread sheet of welded ash-flow tuff, and also forms a string of minor flow remnants down an old north-trending valley. (See under 10, "Cata$\log$ of Peneplain Remnants.") The topography beneath this Hinsdale was irregular, with local relief of at least 800 feet within a mile, and there was actually a valley where Atwood and Mather (1932, pl. 2) showed a north-trending ridge (pl. 1). The drainage was northward toward the subsided area around the Creede caldera and represents local rather than regional canyon cutting.

The patches of Hinsdale Formation (Larsen and Cross, 1956), northwest of area 25, plate 1 , rest generally on Piedra Rhyolite (Larsen and Cross, 1956, pl. 1), which consists of interlayered densely welded to nonwelded ash-flow tuffs. Larsen and Cross' geologic map (1956, pl. 1) indicates that the contact between the Hinsdale and the Piedra here is nearly flat over wide areas, but that locally it cuts abruptly across contours as if jumping from the top of one layer to the top of another. A few of the Hinsdale patches abut and wedge out southward against the local accumulation of relatively young quartz latitic lavas centered in the Summitville area that stood as much as 2,000 feet higher than the adjacent terrain. (See under 25, "Catalog of Peneplain Remnants.") The Hinsdale thus appears to have flowed out over a local piedmont plain at the northern base of a highland area of domal quartz latitic flows, and the general topography had no resemblance to a peneplain.

The largest and laterally most persistent exposures of Hinsdale Formation (Larsen and Cross, 1956), are in the southeastern part of the San Juan Mountains near the Conejos River and northward along the east margin of the mountains (pl. 1). In this same area the Los Pinos Gravel forms a widespread layer between the Hinsdale flows and the older rocks. Atwood and Mather (1932, p. 21, 25) attributed these relations to a general downwarping of the San Juan peneplain in this area, followed by marginal accumulation of gravel as alluvial fans, which in turn were covered by Hinsdale flows. As noted earlier, more recent work (Butler, 1946; Larsen and Cross, 1956; and P. W. Lipman, oral commun., 1966), showed that most of the debris in the Los Pinos was supplied by contemporaneous volcanism rather than by erosion of preexisting rocks. According to P. W. Lipman, the Los Pinos covered an erosion surface of low relief, probably a pediment, cut across the underlying ash-flow tuffs and related rocks. (See No. 24, "Catalog of Peneplain Remnants.") Also, the contact between the ash-flow tuffs and the underlying Conejos Formation and probably the contact between the Los Pinos and the overlying Hinsdale flows are similar ercsional surfaces. These unconformities thus may represent recurrent marginal pedimentation that did not extend to the areas of irregular topography toward the center of the volcanic pile.

\section{POSTPENEPLAIN DEVELOPMENT OF DRAINAGE}

The generally radial drainage pattern of the present San Juan Mountains reflects outward flow of consequent streams from the center of the domed San Juan peneplain area. The Animas River is an exception; it cut downward rapidly enough to keep pace with uplift and to maintain its course across the crest of the dome.

The radial drainage pattern of the San Juan Mountains does indicate outward flow from a central high area, but this high area includes the main source areas for the volcanic accumulations, and represents an original constructional feature of the volcanic field. The two exceptions to the general 
radial drainage, the Animas River and the Rio Grande, owe their anomalous courses across the central high area to the influence of volcano-tectonic collapse structures.

The main tributaries in the headwaters of the Animas River, from the vicinity of Silverton upstream, closely follow the faulted margin of the Silverton cauldron. Erosion along this zone of more broken rock was particularly effective and enabled the Animas River to extend its headwater tributaries across the highest part of the mountains in this vicinity. Downstream from Silverton the Animas River appears to be a typical radial stream except that it has superimposed its course across hard Precambrian rocks along the west flank of the Needle Mountain dome.

The Rio Grande heads in the western San Juan Mountains and flows eastward across the range to the San Luis Valley at Del Norte. Its course across the central San Juans follows the general trend of an east-trending broad syncline and in detail is closely controlled by the Creede caldera and related tangential grabens. Volcano-tectonic collapse created a closed basin that extends across most of the central San Juan Mountains. The lower parts of this depression were filled to the point of overflow by sediments of the Creede Formation, and the drainage that spilled eastward toward the San Luis Valley formed the Rio Grande as we now know it. The drainage basin that forms the headwaters and major source of water for the Rio Grande was thus formed fundamentally by volcano-tectonic collapse, and the course of the river is closely controlled by bedrock structures. Since outflow was established, the erosional history has been largely one of excavation. The Rio Grande has cut down to its present level around the margin of the Creede caldera and has exhumed the domed core of harder rocks. Except for a few deep canyons and many radial gullies, the original form of this dome is strikingly displayed in the modern topography.

\section{POSSIBLE CHARACTER OF THE LATE TERTIARY LANDSCAPE}

If the concept of a peneplain cycle of erosion as envisaged by Atwood and Mather (1932) is untenable, as I believe it to be, what was the character of the landscape of the San Juan area in late Tertiary time? The evidence available is too scanty and too dispersed to support a well-documented picture, but from the few basic elements that can be established, it is possible to reconstruct a conceptual picture of the general terrain that fits the facts as known. The factors considered most pertinent in reconstructing such a picture are these:

1. Only the central, near-source and probably thicker parts of the San Juan volcanic field remain. The north, west, and south margins have been removed by erosion, and the east margin has subsided and been covered by alluvial deposits in the San Luis Valley.

2. Late-volcanism and postvolcanism deformation, probably broadly coincident with sinking of the San Luis Valley segment of the Rio Grande trough, is far more widespread than has previously been realized and is responsibile for much of the broad eastward-tilted basin structure of the central part of the volcanic field, as well as for many of the smaller structures.

3. Relict structural-constructional volcanic forms can be recognized most readily in the central part of the volcanic field. More rapid erosion toward the margins of the field has obscured or destroyed these forms elsewhere, particularly in the more highly elevated and deeply dissected western San Juans.

4. Preservation of original forms can be attributed in part, to burial and relatively late removal of cover, but some domal volcanoes that erupted late in the period of volcanic activity appear to have survived as topographic highs since they originated in late Oligocene or early Miocene time.

5. In the central part of the volcanic field the areas of so-called Hinsdale Formation now are found largely along the edges of former shallow valleys cut into the constructional surface, and they probably represent only minor marginal remnants of formerly much more widely distributed lavas, largely sheetlike flows of basalt.

6. Those remnants of the late Tertiary landscape that can be recognized have a bench-and-table-land aspect typical of many volcanic areas having nearly flat lying formations made up of rocks of widely contrasting resistance to erosion.

7. The San Juan volcanic field was not elevated alone but was involved in the general epeirogenic uplift of the whole Southern Rocky Mountains area in late Cenozoic time. Erosion appears to have been minor until the effects of widespread uplift caused rejuvenation of the streams. The resulting accelerated erosion was regional in extent.

When integrated for that part of the San Juan volcanic field that remains, these elements suggest a somewhat modified original surface of volcanic 
accumulation. The central, near-source area was a bench-and-tableland terrain of relatively low to moderate relief, surmounted by the exposed tops of still mostly buried older hills of diverse origin and by widely scattered late domal volcanoes as much as several thousand feet high. The shallow valleys were partly covered by sheetlike flows of basalt. Most of the exposed rocks belonged to the youngest volcanic units, and locally, as around the Creede caldera, parts of the terrain had actually been built up by filling of the lower parts of volcano-tectonic collapse structures with stream and lake sediments. The stream systems seem to have been poorly established in their headwater areas and in part were caught in resistant basalt flows. Evidence for canyon-cutting until late Tertiary (post-Hinsdale) time is lacking, and the stream gradients appear to have been low and base levels high.

Evidence for recurrent erosion is more apparent near the southeast margin of the volcanic field than it is in the central area just discussed. Repeated episodes of pedimentation alternated with major episodes of volcanic accumulation, and in particular the widespread sheet flows of Hinsdale basalts adjacent to lower Alamosa Creek and the Conejos River covered a nearly flat plain. No evidence was seen, however, for deep erosion or canyon cutting during any but the last (post-Hinsdale) period of erosion, and the recurrent pediments seem to represent somewhat modified surfaces of accumulation rather than classic peneplains.

With collapse of the San Luis Valley segment of the Rio Grande trough, and following general epeirogenic uplift of the whole Southern Rocky Mountains region in late Tertiary time, the rejuvenated streams cut deep canyons, removed most of the widespread flows of basalt in the former lowlands, and exhumed much of the buried volcanic terrain in the central San Juans near the Creede caldera. The modern canyons are the only ones for which evidence exists, and they represent the first major deep erosion since the end of volcanic activity. Some of the interfluve areas still have been little affected, and many original constructional hills persist as topographic highs, even though considerably modified.

The general geomorphic history of the San Juan Mountains is thus not unique but seems closely similar to that of other ranges in the Southern Rocky Mountains that were low and partly covered by middle Tertiary sedimentary rocks until regional uplift in late Cenozoic time caused widespread excavation and canyon cutting by rejuvenated streams.

\section{SUMMARY}

When placed in the context of the geologic history required by bedrock geology, many aspects of the concept of a San Juan peneplain become unconvincing, and in places the evidence contradicts the concept itself. The regional and local deformations required before and after the postulated peneplanation cannot be supported from bedrock evidence. Instead, detailed studies have disclosed great volcanic cauldron complexes in the central and western parts of the San Juan Mountains, and in the central San Juans the rough terrain left by caldera collapse is in part reflected in the present topography. Segments of this area appear to have been below the level of posulated peneplanation since the end of volcanic activity. In addition, significant areas of only slightly modified original depositional surfaces still exist near the center of the volcanic accumulation.

The upper course of the Rio Grande is structurally controlled, and the origin of the river is closely related to the volcanic history; a widespread peneplain is precluded in any significant segment of its drainage basin.

Most of the larger summit areas of low relief designated by Atwood and Mather (1932, pl. 2) as remnants of the San Juan peneplain can be accounted for by local factors, and they need never have been integrated into a single surface at any time but the present. Equally important, many highlevel surfaces of low relief were not included as remnants, although most could easily have fit into other plausible ancient landscapes.

The geologic history determined from bedrock geology indicates that the initial surface of relatively low relief resulting from accumulation of the volcanic materials persisted with only minor modification until late Tertiary time, when general epeirogenic uplift of the Southern Rocky Mountains caused regional rejuvenation and canyon cutting. The extent of late Cenozoic erosion differed considerably from place to place, depending on local conditions, but in general the erosion did not progress beyond the canyon-cutting stage.

\section{CATALOG OF PENEPLAIN REMNANTS}

$\begin{array}{cc}\text { Key No. Coordinates } \\ 1 & 6-\mathrm{C}, \mathrm{D}\end{array}$

The tops of Fitzpatrick Mesa, Black Mesa, and Soap Mesa are stripped surfaces on, and parallel to, warped layers of welded ash-flow tuffs (W. R. 


\section{Key No. Coordinates \\ $16-\mathrm{C}, \mathrm{D}$ \\ (Con.) (Con.)}

$5,6-\mathrm{C}, \mathrm{D}$

3

$5,6-\mathrm{C}, \mathrm{D}$

4

6-E
Discussion

Hansen, oral commun., 1964). The Bayfield Gravel shown by Atwood and Mather (1932, pl. 2) in this area is interlayered with the ash-flow sequence. Only the higher mesa surfaces were interpreted as peneplain remnants, although similar stripped surfaces on lower resistant layers are numerous in the area.

According to Cross, Howe, and Irving $(1907$, p. 13): "In the northeast corner of the [Ouray] quadrangle is a small area representative of the plateau country that is more prominent farther east in the Lake City quadrangle. The gently undulating surface is common where the surface flows of the Potosi formation [welded ash-flow tuffs] have any considerable lateral extent. In this case the San Juan [Formation] forms Park Mesa [Trident Mesa, or High Mesa], but the horizon of the Potosi is just above it." Thus several different horizons are represented by the stripped surfaces in this area. Only the larger of these local surfaces were interpreted to be peneplain remnants. Higher mesas of more limited extent were called monadnocks, and lower benches were ignored. Identical horizons within the Potosi were shown as tops of monadnocks along the Trident Mesa Ridge but were included as peneplain remnants along the ridges to the east.

The longer, north-trending peneplain remnants east and southeast of Trident Mesa (see 2) all coincide with areas shown by Larsen and Cross (1956, pl. 1) as Alboroto Rhyolite-a formation which in adjacent areas consists of differentially welded ash-flow tuffs (W. R. Hansen, oral commun., 1964 ; J. C. Olson and D. C. Hedlund, oral commun., 1964). The discussion under 2 gives the topographic relationships of the remnants near this point.

Carpenter Ridge (west of Cebolla Creek) and the Big Mesa area (east of Cebolla Creek) are underlain by welded ash-flow tuffs (Olson, J. C., oral commun., 1964). The peneplain remnants coincide with stripped surfaces on hard, densely welded layers; different horizons are represented in different remnants, and a unit that underlies a mesa cap in one place may underlie a lower bench in another.

This remnant coincides with the top of Huntsman Mesa and, according $\begin{array}{cc}\text { Key No. } & \text { Coordinates } \\ 5 & 6-\mathrm{E}, \mathrm{F} \\ \text { (Con.) } & \text { (Con.) }\end{array}$

$65,6-\mathrm{E}, \mathrm{F}$

7

4, 5-C

8

4-E

$9 \quad 4-F, G$
Discussion

to D. C. Hedlund (oral commun., 1964), reflects a capping of hard quartzitic sandstone of Jurassic age.

J. C. Olson (oral commun., 1964) reported that the southernmost of these two remnants is underlain by a thick unit of welded ash-flow tuff and that the surface is generally parallel to the tuff layering. The northernmost remnant is underlain largely by the same hard quartzitic sandstone unit discussed under 5, above. Much of the area embracing 4, 5, and 6 is underlain by flat-lying sedimentary strata and ash-flow tuff units, and it has a typical bench-and-tableland topography reflecting differential erosion of interlayered hard and soft rocks.

This remnant coincides in large part with the so-called intrusive American Flat Latite (Cross and others, 1907, p. 11). Luedke and Burbank (1961) have shown this to be an ash-flow tuff. The peneplain remnant largely exposes hard, densely welded tuff from which the overlying soft tuff has been stripped. In places the surface is on hard welded tuffs in the Potosi Volcanic Group (Luedke and Burbank, 1963) that unconformably overlies the American Flat Latite.

Reconnaissance connected with my own detailed work near Creede has shown these two remnants to be stripped surfaces on densely welded tuff in the Nelson Mountain Quartz Latite (Steven and Ratté, 1964), the youngest ash-flow unit to have been deposited in this area. Younger lavas of Fisher Quartz Latite overlie the Nelson Mountain tuffs just north of these remnants, and the position of the contact indicates that the remnants are only slightly reduced from the original constructional surface of the area. Only a small thickness of nonwelded to partially welded tuff seems to have been removed. Stripped surfaces on lower resistant layers, particularly the Wason Park Rhyolite, are excellently developed in this area. The surface remnant several miles north is a slightly modified original flow top in the Fisher Quartz Latite.

My own detailed and reconnaissance studies have shown most of these remnants to be stripped surfaces on hard welded ash-flow tuff layers in the Nelson Mountain Quartz Latite, 


$\begin{array}{cc}\text { Key No. } & \text { Coordinates } \\ 9 & 4-\mathrm{F}, \mathrm{G} \\ \text { (Con.) } & \text { (Con.) }\end{array}$

10

3-F, G

11

\section{Discussion}

the youngest volcanic unit to have been deposited in this area.

The northeast-trending remnant is of a different origin, and I lack specific evidence concerning it.

This remnant is interpreted from a series of small patches of basalt of the Hinsdale Formation. I have mapped this area in detail, and the basalt in part forms a mesa capping on top of the Wason Park Rhyolite, a widespread densely welded ashflow tuff, and in part forms minor flow remnants in a north-trending valley. The pre-Hinsdale topography had little resemblance to a peneplain, as local relief was at least 800 feet within a mile.

The remnants to the north and to the south of the point represent the tops of Fisher and Beautiful Mountains, respectively. Both of these mountains are domal lava flows of Fisher Quartz Latite, and the so-called peneplain remnant marking the top of Fisher Mountain may reflect a somewhat modified original flow top (Steven, 1964 , p. D125). The surface of much of the immediately adjacent areas may never have attained the height of the San Juan peneplain shown by Atwood and Mather (1932, pl. 2).

Some of the small remnants to the east are surfaces of Fisher Quartz Latite flows, and the others are stripped surfaces on older welded ash-flow tuffs.

This remnant is the top of Snowshoe Mountain, the highest part of the domed core of the Creede caldera. The rounded summit area has been reduced in height an unknown amount but probably was never covered by a younger unit, and it has projected above adjacent areas ever since doming in mid-Tertiary time. The surface around most of the margin of the Creede caldera probably was never as high as the level of the San Juan peneplain shown by Atwood and Mather (1932, pl. 2).

The remnant just west of the point is a stripped surface on a hard welded ash-flow tuff in the Potosi Volcanic Group (Luedke and Burbank, 1963). Extensive stripped surfaces at the same and other horizons exist in an area with striking bench-and-tableland topography just north of the Rio Grande in this vicinity.

As mapped by Cross, Howe, Irving, and Emmons (1905), this remnant ex- $\begin{array}{cl}\text { Key No. } & \text { Coordinates } \\ 14 & 3,4--\mathrm{C}, \mathrm{D} \\ \text { (Con.) } & \text { (Con.) }\end{array}$

15

3, 4-B

16

$3,4-\mathrm{A}$

17

2, 3-A

18
Discussion

poses hard Precambrian rocks over most of its area, but one small patch of Devonian Ouray Limestone remains, and indicates that it is largely an exhumed remnant of an early Paleozoic surface. A photograph of this surface remnant is shown by Atwood and Mather (1932, pl. 21A).

As mapped by Cross and Hole (1910), the northwest end of this remnant is a stripped surface in part on a sheetlike igneous intrusion and in part on a resistant bed in the Dakota Sandstone which overlies the intrusion. The east- and north-trending segments of the remnant expose a variety of rock units, but they show little resemblance to a plain. Modern largescale topographic maps (Hermosa Peak and Engineer Mountain quadrangles, 7.5-minute series, U.S. Geol. Survey, 1960) show no flat areas; slopes are rarely less than 400 feet per mile; and the ridge crests do not appear to be accordant.

As mapped and described by Cross and Ransome (1905), the three remnants of the San Juan peneplain west of Rico are stripped surfaces on inclined resistant sandstone beds in the lower part of the Dakota Sandstone. The westerly dips are part of the domed structure around the Rico laccolithic center, and doming preceded erosion.

This long narrow northwest-trending peneplain remnant corresponds almost exactly to a remnant of Dakota Sandstone mapped by Cross and Ransome (1905).

As described by Cross, Spencer, and Purington (1899, p. 2): "The southern third of the La Plata quadrangle belongs physiographically to the eastern extension of the Mesa Verde, a plain normally some 2,000 feet above the level of the Dolores Plateau. This high level is maintained as a plateau by the preservation of massive Cretaceous sandstones which have been entirely removed over the large area of the Dolores and Great Sage plains [to the north]." All the peneplain remnants in this vicinity are within the area mapped by Cross, Spencer, and Purington as Mesaverde Formation, and all are parallel to the underlying inclined beds that dip radially off the La Plata dome. Doming resulted from igneous intrusion and clearly preceded erosion.

The area was mapped in more detail 


$\begin{array}{cc}\text { Key No. } & \text { Coordinates } \\ 18 & 2-\mathrm{A} \\ \text { (Con.) } & \text { (Con.) }\end{array}$

19

2-A, B

20

2-B, C

21

$2,3-\mathrm{C}$
Discussion
by Zapp (1949), and his map emphasizes the restriction of these peneplain remnants to areas underlain by the Mesaverde Group.

The remnants of the San Juan peneplain on the east flank of the La Plata Mountains are partly within the area mapped by Eckel (1949). In part, these appear to reflect dip slopes on inclined sedimentary beds that were domed by igneous intrusion. Only the remnant southwest of the point (the Wild Oat Mesa area) has sufficiently low relief to qualify as a possible representative of a plain. The remnants north and east of the point have irregular surfaces with many steep-sided hills projecting above them; these remnants seem unconvincing as evidence for a former peneplain.

This is the area in which Atwood and Mather (1932, p. 22) first conceived of a San Juan peneplain, and their description has been given. (See "The Peneplain Concept.") The surface bevels several different formations, largely sedimentary units of late Paleozoic and Mesozoic age, and it seems quite likely that it truly represents a remnant of an old erosion surface of undetermined age or -extent.

The geologic map of Cross, Howe, Irving, and Emmons (1905) indicates that the remnants of the San Juan peneplain in the vicinity of this point are either stripped dip slopes on resistant lower Paleozoic sedimentary rocks or exhumed remnants of the early Paleozoic surface on which these formations were originally laid down. Photographs of two of the dip slopes (Lime Mesa and Stag Mesa) are shown as figures 1 and 2 in the Cross, Howe, Irving, and Emmons report. The nearby smooth surface remnants on Precambrian rocks either have scattered patches of Cambrian Ignacio Quartzite on them or are clearly on projection from nearby remnants with such patches. The inclined beds were upwarped as part of the Needle Mountains dome, which formed before the Tertiary volcanic rocks were erupted.

The linear remnants of the San Juan peneplain extending east from $\mathrm{Du}$ rango are all accordant narrow ridge crests along a sharp south-dipping monocline (Zapp, 1949, sheet 2; Barnes, 1953). The ridges consist

$\begin{array}{cl}\text { Key No. } & \text { Coordinates } \\ 22 & 2-\mathrm{C} \\ \text { (Con.) } & \text { (Con.) }\end{array}$

1-E, F
Discussion

largely of resistant sandstone beds in the Mesaverde Group, the Pictured Cliffs Sandstone, the Farmington Sandstone Member of the Kirtland Shale, and the McDermott Formation. Although generally accordant, most ridge crests are narrow and are unconvincing as evidence of a former plain.

The large three-pronged remnant to the northeast is in the lower part of a sequence of Cretaceous sedimentary rocks that Larson and Cross (1956, pl. 1) mapped as a unit. Published data are inadequate to determine specifically which formations underlie the remnant, but its position at and near the base of the Cretaceous section suggests that the Dakota Sandstone is exposed under at least part of it.

This remnant of the San Juan peneplain is the top of Archuleta Mesa, which Wood, Kelley, and MacAlpin (1948) and Dane (1948) described as a nearly flat sill of augite andesite in the Animas Formation of Late Cretaceous and Paleocene age. The softer sedimentary rocks have been stripped from the hard, resistant igneous rock.

1-G, H, I Most of the remnants flanking the Conejos River in this vicinity are within an area mapped in 1966 by P. W. Lipman (oral commun., 1966). The underlying rocks are largely differentially welded ash-flow tuffs that form widespread thin sheets generally 100 feet or less thick. These tuffs dip as much as $10^{\circ} \mathrm{E}$., and most of the peneplain remnants reflect stripped surfaces on inclined layers of densely welded tuff. Only the higher inclined benches at any one locality were included as peneplain remnants.

Unconformities representing erosional surfaces of low relief (pediments?) separate the ash-flow tuffs from the underlying andesitic to rhyodacitic lavas and breccias of the Conejos Formation and from the overlying Los Pinos Gravel. A more obscure erosional surface separates the Los Pinos from the overlying basaltic lavas of the Hinsdale Formation. The unconformity at the base of the ashflow tuffs represents the greatest erosion. The upper two unconformities appear to represent only minor beveling of the original surfaces of deposition. The lowest unconformity is 


$\begin{array}{cl}\text { Key No. } & \text { Coordinates } \\ 24 & 1-\mathrm{G}, \mathrm{H}, \mathrm{I} \\ \text { (Con.) } & \text { (Con.) } \\ 25 & 2,3-\mathrm{G}\end{array}$

definitely below any of the stratigraphic positions proposed for the San Juan peneplain in this vicinity.

These small remnants of the San Juan peneplain are of several origins. The two small areas east of the point are exhumed fragments of an erosion surface that once separated the Conejos Formation from overlying relatively young quartz latitic lavas. This surface was not a plain but appears to have had a hilly topography with a relief of 2,000 feet within a few miles (Steven and Ratté, $1960 \mathrm{a}$, p. 9 and pl. 1). The younger lavas built a local pile of viscous flows, domes, and related breccias with a rough local topography that stood above the adjacent terrain (Steven and Ratté, $1960 a$, p. 31-36). The two remnants to the northwest are somewhat modified original flow tops in the younger lavas, but the origin of the remnant to the north is not clear. Much of the area adjacent to this local accumulation was probably well below the level postulated for the San Juan peneplain in this vicinity.

\section{REFERENCES CITED}

Atwood, W. W., and Mather, K. F., 1932, Physiography and Quaternary geology of the San Juan Mountains, Colorado: U.S. Geol. Survey Prof. Paper 166, 176 p.

Baltz, E. H., 1965, Stratigraphy and history of Raton basin and notes on San Luis basin, Colorado-New Mexico: Am. Assoc. Petroleum Geologists Bull., v. 49, no. 11, p. 2041-2075.

Barnes, Harley, 1953, Geology of the Ignacio area, Ignacio and Pagosa Springs quadrangles, La Plata and Archuleta Counties, Colorado: U.S. Geol. Survey Oil and Gas Inv. Map OM-138.

Blackwelder, Eliot, 1909, Cenozoic history of the Laramie region, Wyoming: Jour. Geology, v. 17, p. 429-444.

Bromfield, C. S., 1961, Emplacement of the Wilson Peak stock and associated intrusive rocks, San Miguel Mountain, Colorado, in Short papers in the geologic and hydrologic sciences: U.S. Geol. Survey Prof. Paper 424-C, p. C137-C139.

Bromfield, C. S., and Conroy, A. R., 1963, Preliminary geologic map of the Mount Wilson quadrangle, San Miguel County [and Dolores County], Colorado: U.S. Geol. Survey Mineral Inv. Field Studies Map MF-273 [1964].

Burbank, W. S., 1933, Vein systems of the Arrastre Basin and regional geologic structure in the Silverton and Telluride quadrangles, Colorado: Colorado Sci. Soc. Proc., v. 13, no. 5, p. 135-214.

Burbank, W. S., 1940, Structural control of ore deposition in the Uncompahgre district, Ouray County, Colorado, with suggestions for prospecting: U.S. Geol. Survey Bull. 906-E, p. 189-265 [1941].

Burbank, W. S., and Lovering, T. S., 1933, Relation of stratigraphy, structure, and igneous activity to ore deposi- tion of Colorado and southern Wyoming, in Ore deposits of the Western States (Lindgren volume): New York, Am. Inst. Mining Metall. Engineers, p. 272-316.

Bush, A. L., Bromfield, C. S., Marsh, O. T., and Taylor, R. B., 1961, Preliminary geologic map of the Gray Head quadrangle, San Miguel County, Colorado: U.S. Geol. Survey Mineral Inv. Field Studies Map MF-176.

Bush, A. L., Marsh, O. T., and Taylor, R. B., 1960, Areal geology of the Little Cone quadrangle, Colorado: U.S. Geol. Survey Bull. 1082-G, p. 423-492 [1961].

Butler, A. P., Jr., 1946, Tertiary and Quaternary geology of the Tusas-Tres Piedras area, New Mexico: Cambridge Mass., Harvard Univ., unpub. Ph. D. thesis.

Cross, Whitman, and Hole, A. D., 1910, Description of the Engineer Mountain quadrangle [Colo.]: U.S. Geol. Survey Geol. Atlas, Folio 171.

Cross, Whitman, Howe, Ernest, and Irving, J.D., 1907, Description of the Ouray quadrangle [Colo.]: U.S. Geol. Survey Geol. Atlas, Folio 153.

Cross, Whitman, Howe, Ernest, Irving, J. D., and Emmons, W. H., 1905, Description of the Needle Mountains quadrangle [Colo.]: U.S. Geol. Survey Geol. Atlas, Folio 131.

Cross, Whitman, and Larson, E. S., Jr., 1935, A brief review of the geology of the San Juan region of southwestern Colorado: U.S. Geol. Survey Bull. 843, 138 p.

Cross, Whitman, and Ransome, F. L., 1905, Description of the Rico quadrangle [Colo.]: U.S. Geol. Survey Geol. Atlas, Folio 130.

Cross, Whitman, Spencer, A. C., and Purington, C. W., 1899, Description of the La Plata quadrangle [Colo.]: U.S. Geol. Survey Geol. Atlas, Folio 60.

Dane, C. H., 1948, Geology and oil possibilities of the eastern side of San Juan Basin, Rio Arriba County, New Mexico: U.S. Geol. Survey Oil and Gas Inv. (Prelim.) Map 78.

Davis, W. M., 1911, The Colorado Front Range, a study in physiographic presentation: Am. Assoc. Geographers Annals, v. 1, p. 21-84.

Eckel, E. B., 1949, Geology and ore deposits of the La Plata district, Colorado, with sections by J. S. Williams, F. W. Galbraith, and others: U.S. Geol. Survey Prof. Paper 219, 179 p. [1950].

Kelley, V. C., 1955, Regional tectonics of the Colorado Plateau and relationship to the origin and distribution of uranium; New Mexico Univ. Pubs. Geology, no. 5, $120 \mathrm{p}$.

1957, General geology and tectonics of the western San Juan Mountains, Colorado, in New Mexico Geol. Soc. Guidebook 8th Field Conf., September 1957, Southwestern San Juan Mountains, Colorado: p. 154-162.

Larson, E. S., Jr., and Cross, Whitman, 1956, Geology and petrology of the San Juan region, southwestern Colorado: U.S. Geol. Survey Prof. Paper 258, 303 p.

Lee, W. T., 1922, Peneplains of the Front Range and Rocky Mountain National Park, Colorado: U.S. Geol. Survey Bull. 730-A, p. 1-17.

Little, H. P., 1925, Erosional cycles in the Front Range of Colorado and their correlation (with discussion): Geol. Soc. America Bull., v. 36, no. 3, p. 495-512.

Luedke, R. G., and Burbank, W. S., 1961, Central vent ashflow eruption, western San Juan Mountains, Colorado, in Short papers in the geologic and hydrologic sciences: U.S. Geol. Survey Prof. Paper 424-D, p. D94-D96. 
Luedke, R. G., and Burbank, W. S., 1962, Geology of the Ouray quadrangle, Colorado: U.S. Geol. Survey Geol. Quad. Map GQ-152.

1963, Tertiary volcanic stratigraphy in the western San Juan Mountains, Colorado, in Short papers in geology and hydrology: U.S. Geol. Survey Prof. Paper 475-C, p. C39-C44.

Mather, K. F., 1925, Physiographic surfaces in the Front Range of northern Colorado and their equivalents on the Great Plains [abs.]: Geol. Soc. America Bull., v. 36, no. 1, p. 134-135.

Powell, W. J., 1958, Ground-water resources of the San Luis Valley, Colorado, with a section on An inflowoutflow study of the area, by P. B. Mutz: U.S. Geol. Survey Water-Supply Paper 1379, 284 p.

Richmond, G. M., 1965, Quaternary stratigraphy of the Durango area, San Juan Mountains, Colorado, in Geological Survey Research 1965: U.S. Geol. Survey Prof. Paper 525-C, p. C137-C143.

Shoemaker, E. M., 1956, Structural features of the central Colorado Plateau and their relation to uranium deposits, in Page, L. R., Stocking, H. E., and Smith, H. B., compilers, Contributions to the geology of uranium and thorium by the United States Geological Survey and Atomic Energy Commission for the United Nations International Conference on Peaceful Uses of Atomic Energy, Geneva, Switzerland, 1955: U.S. Geol. Survey Prof. Paper 300, p. 155-170.

Simpson, G. G., 1948, The Eocene of the San Juan Basin, New Mexico: Am. Jour. Sci., pt. 1, v. 246, no. 5, p. 257282 ; pt. 2, v. 246 , no. 6 , p. 363-385.

Steven, T. A., 1964, Geologic setting of the Spar City district, San Juan Mountains, Colorado, in Short papers in geology and hydrology: U.S. Geol. Survey Prof. Paper 475-D, p. D123-D127.

Steven, T. A., Mehnert, H. H., and Obradovich, J. D., 1967, Age of volcanic activity in the San Juan Mountains, Colorado, in Geological Survey research 1967: U.S. Geol. Survey Prof. Paper 575-D, p. D47-D55.

Steven, T. A., and Ratté, J. C., 1960a, Geology and ore deposits of the Summitville district, San Juan Mountains, Colorado: U.S. Geol. Survey Prof. Paper 343, 70 p.

1960b, Relation of mineralization to caldera subsidence in the Creede district, San Juan Mountains, Colorado, in Short papers in the geological sciences: U.S. Geol. Survey Prof. Paper 400-B, p. B14-B17.

1964, Revised Tertiary volcanic sequence in the central San Juan Mountains, Colorado, in Short papers in geology and hydrology: U.S. Geol. Survey Prof. Paper 475-D, p. D54-D63.

1965, Geology and structural control of ore deposition in the Creede district, San Juan Mountains, Colorado: U.S. Geol. Survey Prof. Paper 487, 90 p.

Van Houten, F. B., 1957, Appraisal of Ridgway and Gunnison "tillites," southwestern Colorado: Geol. Soc. America Bull., v. 68, p. 383-388.

Van Tuyl, F. M., and Lovering, T. S., 1935, Physiographic development of the Front Range: Geol. Soc. America Bull., v. 46, p. 1291-1350.

Wood, G. H., Jr., Kelley, V. C., and MacAlpin, A. J., 1948, Geology of the southern part of Archuleta County, Colorado: U.S. Geol. Survey Oil and Gas Inv. (Prelim.) Map 81.

Zapp, A. D., 1949, Geology and coal resources of the Durango area, La Plata and Montezuma Counties, Colorado: U.S. Geol. Survey Oil and Gas Inv. (Prelim.) Map 102 (2 sheets). 
